\title{
White Shrimp (Litopenaeus vannamei) Culture using Heterotrophic Aquaculture System on Nursery Phase
}

Supono ${ }^{1^{*}}$, Johannes Hutabarat ${ }^{2}$, Slamet Budi Prayitno ${ }^{2}$ and YS Darmanto ${ }^{2}$

${ }^{1}$ Department of Aquaculture, Faculty of Agriculture, Lampung University, Indonesia

${ }^{2}$ Department of Fisheries, Faculty of Fisheries and Marine Science, Diponegoro University, Indonesia

*Corresponding author: Supono, Department of Aquaculture, Faculty of Agriculture, Lampung University, Indonesia, Tel: +628127240191; E-mail: supono_unila@yahoo.com

Received date: January 9, 2014; Accepted date: April 16, 2014; Published date: April 23, 2014

Copyright: @2014 Supono, et al. This is an open-access article distributed under the terms of the Creative Commons Attribution License, which permits unrestricted use, distribution, and reproduction in any medium, provided the original author and source are credited.

\begin{abstract}
Heterotrophic aquaculture system is an environmental friendly shrimp culture that has a huge potency to improve yields of Litopenaeus vannamei. Biofloc grown in a heterotrophic aquaculture system that can be used as an alternative feed for shrimp due to its high nutrition. Biofloc contains bacterial protein and polyhydroxybutyrate that are able to enhance growth. Biofloc also contains bacteria that have peptidoglycan and lipopolysaccharide on their cell walls. The aim of the research was to study the effect of heterotrophic aquaculture system on culturing of Litopenaeus vannamei during nursery phase. The experiment was arranged in split plot design in three replicateses. The treatments consisted of two factors namely various densities and different aquaculture systems. The aquaculture systems were autotrophic and heterotrophic aquaculture system, while densities were 1,000, 1,500, and 2,000 $\mathrm{PLm}^{-3}$. The result showed that there was no significant interaction between densities and aquaculture system toward the growth rate, protein efficiency ratio and yield of Litopenaeus vannamei. The heterotrophic aquaculture system was able to increase the yield of Litopenaeus vannamei on nursery phase. However heterotrophic aquaculture system did not significantly affect growth rate and protein efficiency ratio of Litopenaeus vannamei. While, the density significantly affected survival rate and yield of Litopenaeus vannamei.
\end{abstract}

Keywords: Environmental friendly; Litopenaeus vannamei; Heterotrophic; Biofloc

\section{Introduction}

The intensive development of the shrimp culture has been accompanied by an enhancement in environmental impact. In the autotrophic aquaculture system, waste of shrimp culture can be a serious problem both in culture pond and in the environment. The effluent as uneaten feed, faces, and excretions is mostly inorganic nitrogen (mobile nitrogen) in form of ammonia and nitrite due to high protein content in feed (30-40\%). Nitrogen in feed is only $25 \%$ that is recovered in the shrimp on harvest while about $75 \%$ is released into the pond ecosystem, mostly as TAN [1]. Ammonia and nitrite in culture pond is toxic to shrimp. Inorganic nitrogen built up in ponds, is controlled by algae and nitrification. Inorganic nitrogen is converted to organic nitrogen to build algae cell. This process is limited by the rate carbon assimilation by algae. Nitrification is a slow process and need a few weeks to complete it [2].

In order to minimalize impact of the shrimp culture effluent, it is impotant to develope shrimp farming with zero water exchange. The effluent produced by shrimp should be recycled in the pond before releasing to the surrounding environment. The method that can be applied to overcome the problem is heterotrophic aquaculture system (biofloc system). A carbon source namely sugar, molasses, and starch is added into culture pond increasing ratio of C:N to immobilize inorganic nitrogen and to stimulate the growth of heterotrophic bacteria to form biofloc.

The shrimp cultivated in heterorophic system has higher price than that in autotrophic system due to an environmental friendly product.
Heterorophic system in aquculture has huge potential to increase growth and survival rate of shrimp. Heterorophic system is capable to decrease cost production from feed because biofloc can be an alternative feed for shrimp that has high nutrition content [2].

Biofloc dominated by bacteria is high protein content and able to produce polyhydroxybutyrate as reserve energy and carbon [3]. Polyhydroxybutyrate is capable to accelerate the animal growth and to inhibit pathogenic vibrio in intestine tract. The objective of this experiment was to study the effect of heterotrophic system on the performance of on nursery Litopenaeus vannamei phase.

\section{Materials and Methods}

The experiment was arranged in split plot design with two factors in three replicates. The treatments consisted of aquaculture system (as sub plot) and density (as main plot). The aquaculture systems were heterotrophic system (HS) and autotrophic system (AS) while stocking densities of Litopenaeus vannamei were 10, 15, and 20 PL in 10 litres container equivalent to $1,000,1,500$, and $2,000 \mathrm{PLm}^{-3}$.

Eighteen plastic containers were filled with sterile saline water. Water salinity was adjusted to osmolarity of Litopenaeus vannamei haemolymph at intermolt phase. Osmolarity of Litopenaeus vannamei haemolymph was measured with method conducted by Anggoro and Muryati [4]. Nine containers were used to culture Litopenaeus vannamei in heterotrophic system. Shrimp feed and glucose was added to get C:N ratio of 21 [2]. Bacterium of Bacillus cereus $\left(10^{6} \mathrm{CFU} / \mathrm{ml}\right)$ was inoculated into media to stimulate heterotrophic system. Each container was equipped by aeration and was installed on the container bottom to maintain dissolved oxygen min. at $4 \mathrm{mg} / \mathrm{l}$ and water movement. After 10 days of growing biofloc, Litopenaeus vannamei 
Citation: Supono, Johannes Hutabarat, Slamet Budi Prayitno, YS Darmanto (2014) White Shrimp (Litopenaeus vannamei) Culture using Heterotrophic Aquaculture System on Nursery Phase. Int J Waste Resources 4: 142. doi:10.4172/2252-5211.1000142

Page 2 of 4

postlarvae (PL 17) with an average body weight of $11 \pm 1.0 \mathrm{mg}$ and average length of $1.36 \pm 0.15 \mathrm{~cm}$ was stocked into culture media.

Shrimp culture was conducted in 30 days. Shrimp were fed by formulated feed of $38 \%$ protein on feeding rate of $5 \%$. Zero water exchange was applied in heterotrophic system. The growth and survival rate of Litopenaeus vannamei were calculated with methods conducted by Far et al. [5]. Protein efficiency ratio was analyzed with a method described by Hoffman and Falvo [6]. All data were further analyzed statistically using Two-Way-Anova after testing of normality, homogenity, and additivity using SPSS statistical software. Statistical significance of differences required that $\mathrm{p}<0.05$.

\section{Results and Discussion}

\section{Haemolymph osmolarity of Litopenaeus vannamei}

Haemolymph osmolarity of PL 11- Litopenaeus vannamei on premolt phase was $933,89 \mathrm{mOsm} / \mathrm{l} \mathrm{H}_{2} \mathrm{O}$, equivalent to $32 \%$, meanwhile haemolymph osmolarity of Litopenaeus vannamei on intermolt phase was $861,00 \mathrm{mOsm} / 1 \mathrm{H}_{2} \mathrm{O}$, equivalent to $29.5 \%$ (Table $1)$.

\begin{tabular}{|l|l|l|}
\hline Phase & Osmolarity $(\mathrm{m} \mathrm{Osm} / \mathrm{l} \mathrm{H} 2 \mathrm{O})$ & Salinity $(\%)$ \\
\hline \multirow{4}{*}{ Premolt } & 1.933 .89 & 32 \\
\cline { 2 - 4 } & 2.933 .90 & 32 \\
\cline { 2 - 3 } & 3.933 .87 & 32 \\
\cline { 2 - 3 } & Average & 32 \\
\hline \multirow{5}{*}{ Intermolt } & 1.861 .02 & 29.5 \\
\cline { 2 - 3 } & 2.860 .98 & 29.5 \\
\cline { 2 - 3 } & 2.860 .98 & 29.5 \\
\cline { 2 - 3 } & Average & 29.5 \\
\hline
\end{tabular}

Table 1: Osmolarity haemolymph of Litopenaeus vannamei.

According to the data, applied salinity of media was $30 \%$. Osmorality of haemolymph on premolt phase and intermolt phase is the best range for growth (4).

\section{Water quality}

Dissolved oxygen, total ammonia nitrogen (TAN), and $\mathrm{pH}$ of culture media of heterotrophic system and autotrophic system are performed at Figures 1,2 and 3, respectively. The range of dissolved oxygen (DO) in culture media was 5.0-8.0 mg/l, TAN was 0.01-0.05 $\mathrm{mg} / \mathrm{l}$, and $\mathrm{pH}$ was $6.8-7.2$. The values were in range for growing Litopenaeus vannamei [5].

\section{Shrimp Performance}

In general, performance of Litopenaeus vannamei in heterotrophic aquaculture system was better than that in autotrophic one. Specific Growth Rates (SGR), survival Rate (SR), protein efficiency ratio (PER), and yield of Litopenaeus vannamei at harvest are summarized in Table 2.

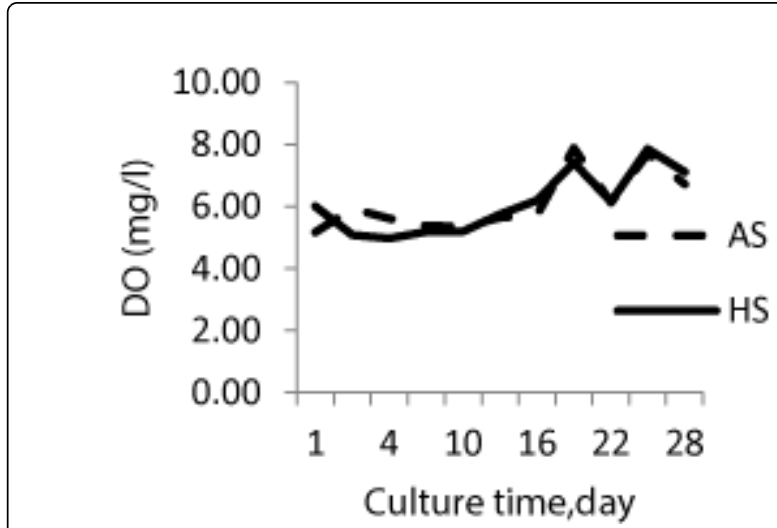

Figure 1: DO of culture media.

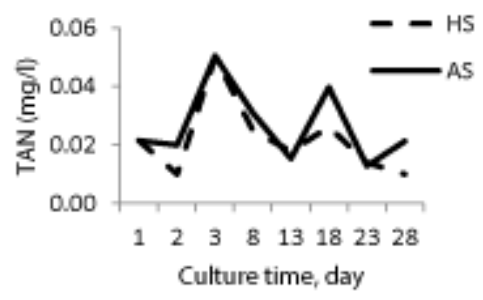

Figure 2: TAN of culture media.

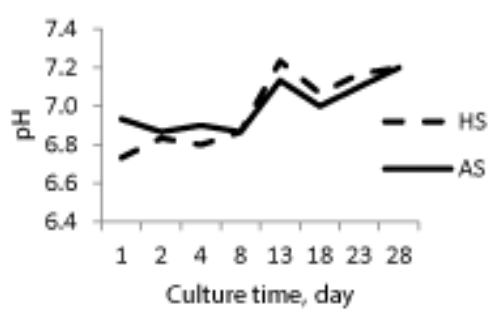

Figure 3: $\mathrm{pH}$ of culture media.

\begin{tabular}{|c|c|c|c|c|c|}
\hline $\begin{array}{l}\text { Density } \\
\left(\mathrm{PL} / \mathrm{m}^{3}\right)\end{array}$ & System & SGR (\%) & SR (\%) & PER & $\begin{array}{l}\text { Yield } \\
\left(\mathrm{g} / \mathrm{m}^{3}\right)\end{array}$ \\
\hline \multirow{2}{*}{1000} & AS & $\begin{array}{l}12.75 \quad \pm \\
2.08\end{array}$ & $60.0 \pm 10.0$ & $0.83 \pm 0.37$ & $\begin{array}{l}256.6 \\
107.8\end{array}$ \\
\hline & HS & $\begin{array}{l}13.07 \quad \pm \\
1.27\end{array}$ & $73.3 \pm 5.8$ & $1.08 \pm 0.35$ & $\begin{array}{l}29.9 \\
101.93\end{array}$ \\
\hline \multirow{2}{*}{1500} & AS & $\begin{array}{l}12.85 \quad \pm \\
2.08\end{array}$ & $60.0 \pm 6.7$ & $0.82 \pm 0.37$ & $\begin{array}{l}378.1 \\
85.7\end{array}$ \\
\hline & HS & $\begin{array}{l}14.04 \quad \pm \\
0.80\end{array}$ & $66.7 \pm 6.7$ & $1.25 \pm 0.26$ & $\begin{array}{l}571.4 \\
114.5\end{array}$ \\
\hline 2000 & AS & $\begin{array}{l}12.90 \quad \pm \\
2.08\end{array}$ & $41.7 \pm 10.4$ & $0.55 \pm 0.10$ & $\begin{array}{l}344.3 \\
59.2\end{array}$ \\
\hline
\end{tabular}


Citation: Supono, Johannes Hutabarat, Slamet Budi Prayitno, YS Darmanto (2014) White Shrimp (Litopenaeus vannamei) Culture using Heterotrophic Aquaculture System on Nursery Phase. Int J Waste Resources 4: 142. doi:10.4172/2252-5211.1000142

Page 3 of 4

\begin{tabular}{|l|l|ll|l|l|ll|}
\hline & HS & $\begin{array}{l}13.15 \\
2.08\end{array}$ & \pm & $50.0 \pm 10.0$ & $0.73 \pm 0.19$ & $\begin{array}{l}450.8 \\
113.6\end{array}$ \\
\hline
\end{tabular}

Table 2: Performance of Litopenaeus vannamei.

According to statistical analytic (ANOVA), there was no significant interaction between densities and aquaculture system to performance of Litopenaeus vannamei. The use of heterotrophic system did not enhance the growth rate and protein efficiency ratio (Figures 4 and 5). However survival rate and yield of Litopenaeus vannamei significantly increased in heterotrophic system (Figures 6 and 7). Stocking densities significantly affected the survival rate and yield of Litopenaeus vannamei.

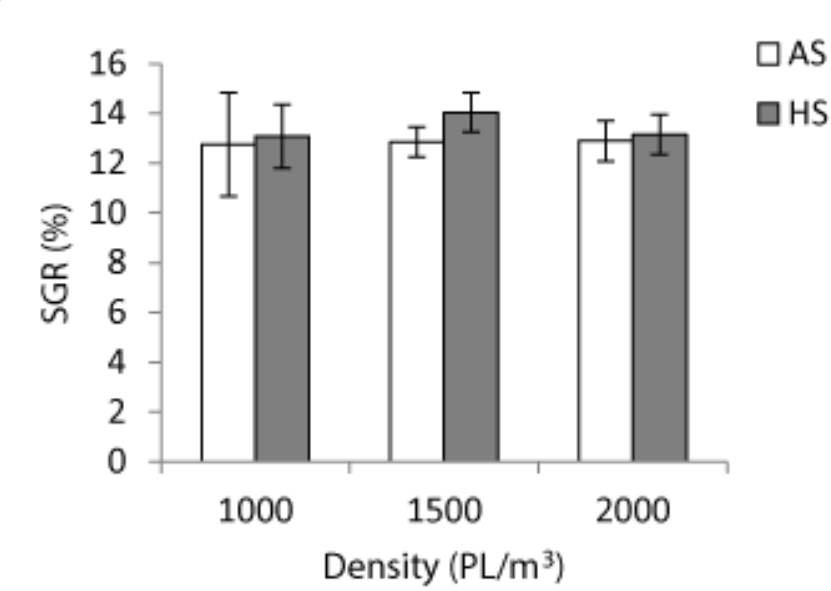

Figure 4: Specific growth rates (SGR) of Litopenaeus vannamei.

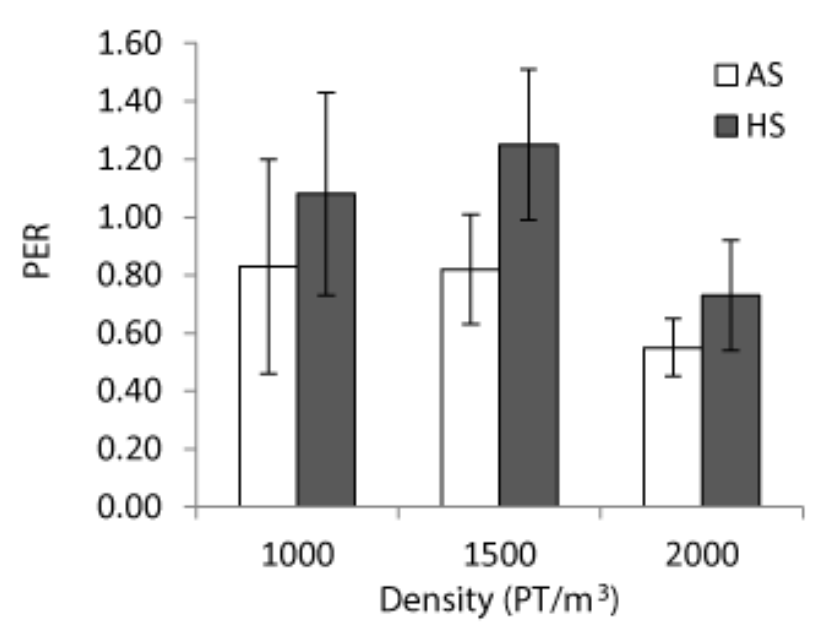

Figure 5: Protein efficiency ratio (PER) of Litopenaeus vannamei.

\section{Discussion}

Ammonia in pond is produced as a major end product of the metabolism due to high content protein of feed and is excreted as ammonia across the gill of shrimp [7]. No water exchange applied in heterotrophic system was able to control TAN in aquaculture system.
By adding organic carbon source to the water, it forces the bacteria to immobilize any inorganic nitrogen present in the pond. Inorganic nitrogen was recycled in the culture pond resulting in microbial protein biomass needed for cell growth and multiplication. At high ratio of $\mathrm{C}: \mathrm{N}$, heterotrophic bacteria will assimilate ammonium nitrogen directly from water metabolized to cell biomass. The addition of carbon source is most effective method in decreasing inorganic nitrogen mostly TAN [7] and is often more stable and reliable than algal uptake or nitrification [1]

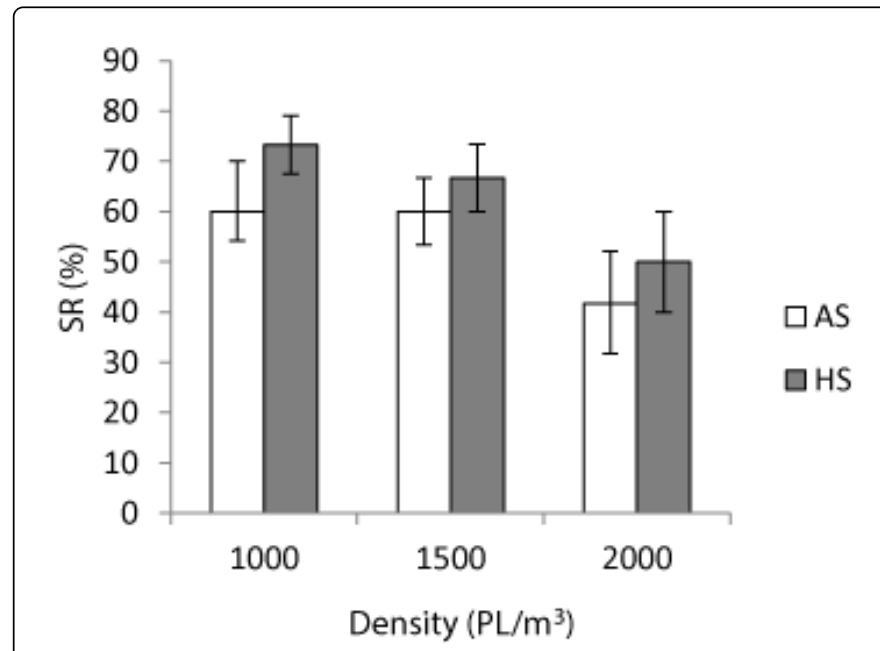

Figure 6: Survival rate (SR) of Litopenaeus vannamei.

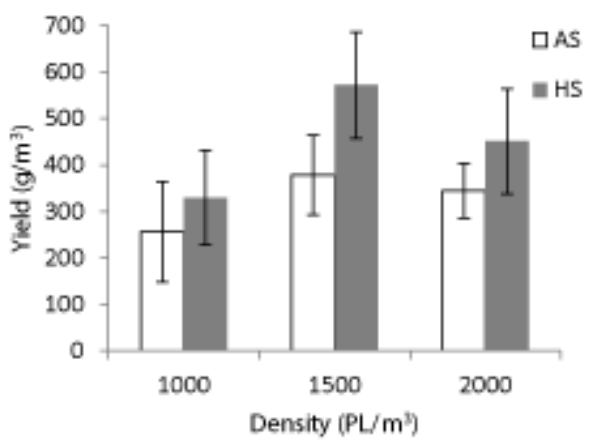

Figure 7: Yields of Litopenaeus vannamei.

Specific growth rates and protein efficiency ratio of Litopenaeus vannamei in heterotrophic aquaculture system tended to be better than those in autotrophic system. Biofloc, formed in heterotrophic system, can be benefited by shrimp as an alternative feed (Figure 8). Biofloc contains bacterial protein [8] and polyhydroxybutyrate [3] produced by bacteria. Biofloc was consumeable due to the appropriate size for shrimp. Polyhydroxybutyrate is the most dominant polymer and is useful in aquaculture. The advantages of PHB are an energy reserve for fish, digestible in intestine, increasing unsaturated fatty acid, and increasing growth of fish [1]. Biofloc also contains methionine, lysine, vitamins and minerals, especially phosphorus 
Citation: Supono, Johannes Hutabarat, Slamet Budi Prayitno, YS Darmanto (2014) White Shrimp (Litopenaeus vannamei) Culture using Heterotrophic Aquaculture System on Nursery Phase. Int J Waste Resources 4: 142. doi:10.4172/2252-5211.1000142

Page 4 of 4

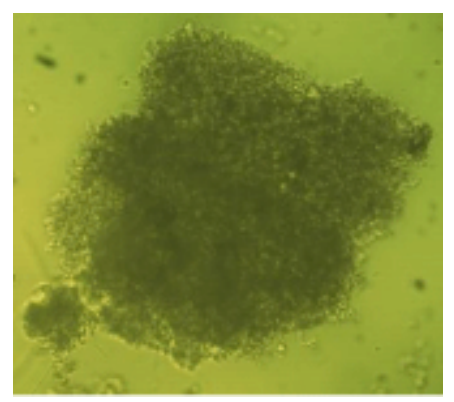

Figure 8: Biofloc.

Survival rate of Litopenaeus vannamei in heterotrophic system experienced enhancement due to biofloc contains bacteria. Bacteria are capable to produce polyhydroxybutyrate. Polyhydroxybutyrate will release 3-hydroxy butyric acid (short chain fatty acid) in the gastro intestinal tract as inhibitor of pathogenic bacteria. According to several researches, PHB is capable to inhibit pathogen in the intestinal tract and to be antimicrobial against Vibrio, E. coli, and Salmonella, to control pathogen of Vibrio harveyi, and to enhance survival rate of Artemia franciscana larvae [9]. Far et al. [5] investigated that Bacillus is able to increase survival rate of Litopenaeus vannamei and to decrease luminous Vibrio densities in the pond water. Bacteria also contain peptydoglycan and lipopolysaccharide on their cell wall. Peptydoglycan and lipopolysaccharide are immunostimulant being capable to inccrease nonspecific immunity of shrimp. The substances influence prophenoloxidase activity and phagocytosis of hyaline cells [10].

The yields of Litopenaeus vannamei in heterotrophic system enhanced significantly compared to autotrophic one. The enhancement was affected by growth (Figure 4) and survival rate (Figure 6). According to polynomial orthogonal analysis, optimal density of Litopenaeus vannamei in autotrophic system on nursery phase was $1612 \mathrm{PL} / \mathrm{m}^{-3}$ yielded $466 \mathrm{~g} / \mathrm{m}^{-3}$, while in heterotrophic system, optimal density was 1638 yielded $639 \mathrm{~g} / \mathrm{m}^{-3}$ (Figure 9). Heterotrophic system was capable to increase yield of Litopenaeus vannamei of $37 \%$ compared to autotrophic system.

\section{Conclusions}

Heterotrophic aquaculture system can be an alternative method to culture Litopenaeus vannamei in pond. The system is environmental-friendly one overcoming the problem in shrimp culture related to deterorietion of environment quality. Pond water quality was controlled resulting in good growth, high survival rate, and increased yield of Litopenaeus vannamei on nursery phase. Heterotrophic system aquaculture was capable to increase the yield of Litopenaeus vannamei on nursery phase. However heterotrophic system did not significantly affect the growth rate and protein efficiency ratio of Litopenaeus vannamei. The density affected the survival rate and yield of Litopenaeus vannamei.

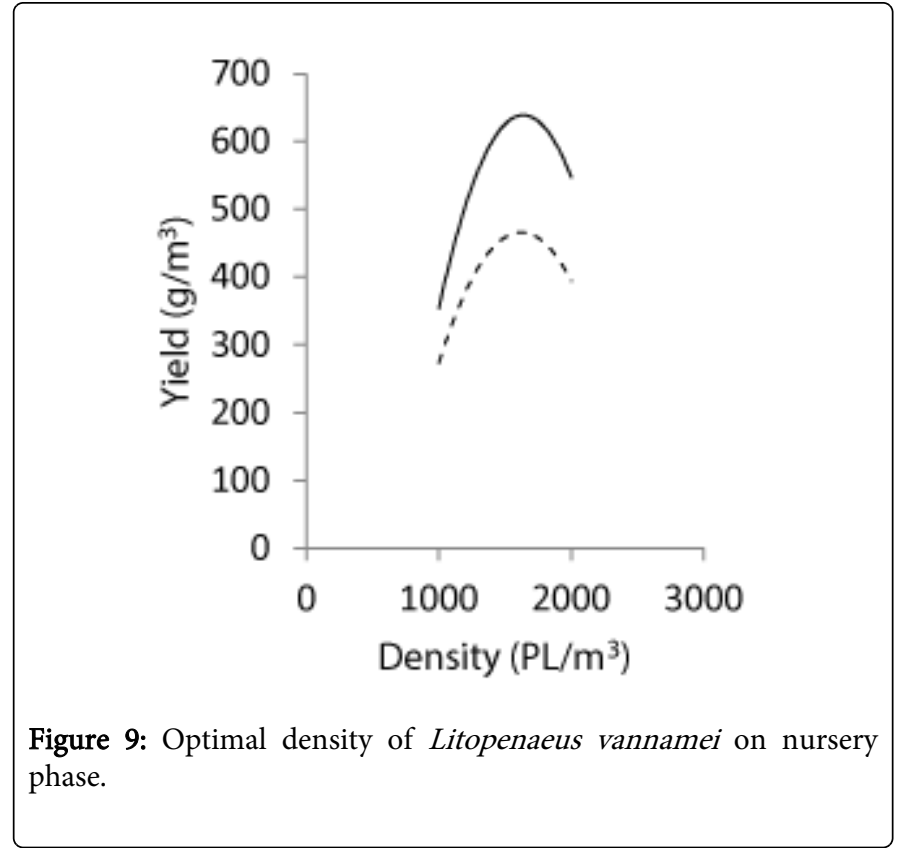

\section{References}

1. Crab R, Avnimelech Y, Defoirdt T, Bossier P, Verstraete W (2007) Nitrogen removal techniques in aquaculture for a sustainable production. Aquaculture 270: 1-14.

2. Avnimelech Y (2009) Biofloc Technology-A Practical Guide Book. The World Aquaculture Society Baton Rounge Louisiana United State.

3. De Schryver P, Sinha AK, Kunwar PS, Baruah K, Verstraete W, et al. (2010) Poly-beta-hydroxybutyrate (PHB) increases growth performance and intestinal bacterial range-weighted richness in juvenile European sea bass, Dicentrarchus labrax. Applied Microbiology and Biotechnology 86: 1535-1541.

4. Anggoro S, Muryati (2006) Osmotic respons of tiger shrimp (Penaeus monodon Fab.) juvenile and adult at various level of molting stages and salinity. Buletin Penelitian dan Pengembangan Industri 1: 59-63.

5. Far HZ, Saad CRB, Daud HM, Harmin SA, Shakibazadeh S (2009) Effect of Bacillus subtilis on the growth and survival rate of shrimp (Litopenaeus vannamei. African Journal of Biotechnology 8: 3369-3376.

6. Hoffman JR, Falvo MJ (2004) Protein - Which is Best? J Sports Sci Med 3: 118-130.

7. Ebeling JM, Michael B. Timmons JJ, Bisogni (2006) Engineering analysis of the stoichiometry of photoautotrophic, autotrophic, and heterotrophic removal of ammonia-nitrogen in aquaculture systems. Aquaculture 257: 346-358.

8. Hargreaves JA (2013) Biofloc Production System for Aquaculture. Southern Rregional Aquaculture Center Publication No: 4503.

9. Crab R, Lambert A, Defoirdt T, Bossier P, Verstraete W (2010) The application of bioflocs technology to protect brine shrimp (Artemia franciscana) from pathogenic Vibrio harveyi. J Appl Microbiol 109: 1643-1649.

10. Yeh ST, Li CC, Tsui WC, Lin YC, Chen JC (2010) The protective immunity oh white shrimp Litopenaeus vannamei that had been immersed in the hot water extract of Gracilaria tenuistipitata and subjected to combined stresses of Vibrio alginolyticus injection and temperature change. Fish \& Shellfish Immunology 29: 271-278. 